\title{
Identity practices of English teachers in Brazilian digital communities
}

\section{DÁnIe Marcelo de Jesus}

Professor Doutor da UFMT - Universidade Federal

de Mato Grosso; Programa de Pós- Graduação

em Estudos de Linguagem (MeEL) da UFMT; Pos-

Doutorado em Estudos Linguísticos e Literários

em Inglês na Universidade de São Paulo. Cuiabá;

Brazil

daniepuc@gmail.com

Abstract: This study investigates the identity practices of three virtual communities directed to English teachers - "English Language Teachers", "English Teachers in Brazil", and "I am an English Teacher" - in order to understand how teachers' professional identities are constructed in the discourse of community members. The study is grounded on Critical Discourse Analysis (Fairclough, 2000). The research methodology is interpretive and the analysis seeks identity representations that materialise in users' linguistic choices. Findings reveal an attempt to set a traditional professional identity for foreign language teachers in their respective communities.

Keywords: Identity, English language teacher, virtual communities.
Resumo: Este estudo investiga práticas identitárias de três comunidades virtuais direcionadas para professores de inglês "English Language Teachers", "English Teachers in Brazil", and "I am an English Teacher" - com a finalidade de entender como as identidades profissionais dos professores são construídas no discurso dos membros dessas comunidades. A metodologia da pesquisa é interpretativa e a análise procurou representações identitárias que são materializadas nas escolhas linguísticas dos usuários. Os resultados revelam uma tentativa de definir uma identidade profissional tradicional para os professores de língua estrangeira nas comunidades observadas.

Palavras-chaves: Identidade, professor de língua inglesa, comunidades virtuais 



\section{Introduction}

In recent years, a growing number of studies in Brazil, with different theoretical perspectives, have focused on identity and reflected a desire to question and understand social settings in the contemporary world (CELANI; MAGALHÃES, 2002; VEREZA, 2002; SANTOS, 2003; GRIGOLETTO, 2006; ASSIS-PETERSON AND SILVA, 2010; FABRÍCIO; MOITA LOPES, 2010). Despite the progress of those studies, few of them describe the construction of teacher identity in online social networks in Brazil (UCHÔA-FERNANDES, 2008; SANTIAGO, 2008; JESUS, 2009).

According to these studies, the digital context has become an environment that supports research concerned with its dynamics and its social effects in teaching practice. Understanding how cyberspace can affect teachers' professional identity is necessary, particularly considering that we live in a time in which cyberculture enters the school without asking for permission and questions our teaching knowledge, informing us that knowledge itself is temporary and fluid.

Computer-mediated society produces new ways of operating with our subjectivity. Therefore, understanding how teachers are presented in digital interactions shows us parameters about the future of language educators.

Supported by this notion as well as by Critical Discourse Analysis (FAIRCLOUGH, 2001), this study investigated how digital communities of English teachers represent their professional identity in Brazil. Two questions guided this research: How do digital communities create the professional identity of English teachers? How do teachers present themselves?

This paper is structured as follows. It begins by summarizing the theoretical concepts that have developed around identity practices. After that, it describes the 
research context and the data collected. Finally, in the concluding part, it discusses results and their implications in teacher education.

\section{Identity discourse and practices}

The field of language studies (MOITA LOPES, 2003) has often shown interest in the issue of identity, which is itself closely related to the concept of language as discourse. It is commonly believed that the use of language is shaped by the different social contexts to which it is exposed. These contexts are created by social and historical practices and define the identity of the subject and his/her position in interactions with others.

It should be noted that this process is ambiguous, contradictory, and volatile, under constant change due to ongoing interaction (WOODWARD, 2000). In contrast, it reveals political, social, and symbolic processes, which are organized through social practices (FAIRCLOUGH, 2001) that provide meanings to the world.

Social discourse practices contribute to the construction of individuals' identities and social relationships, as well as their beliefs and knowledge. Thus, according to this view of language, ideology and power relations are the key to understanding the social dimensions of knowledge, relationships, and social identity.

Ideologies (FAIRCLOUGH, 2001) are meaningful constructions of reality that relate to the physical world and to social relations and identities. They are constructed in various forms and dimensions of discursive practices, which in turn contribute to the production or transformation of dominant relations. Discursive practices constitute the dimension of language use which involves processes of textual production, distribution, and consumption, varying according to the type of discourse and social factors. 
By adopting this theoretical framework, this research seeks to assign a professional identity to the foreign language teacher as a result of discursive practices, which in turn create the social conditions for an individual to be a teacher in the capitalist world, hence forming a complex web of power struggles. This produces various ideologies that feed themselves. Thus, educators may take ideas and attitudes that do not originate in themselves and are imposed so subtly that they are able to claim them as their own.

Therefore, the teacher is often seen as a subjugated subject and a perennial instrument of capitalist relations of production. This notion is profoundly rejected by Fairclough (2001), who claims that discursive practices are able to transform the relationship between power and their respective ideologies.

From this point of view, the teacher, even in a capitalist society, can be an instrument of change, and it is precisely this principle which supports Fairclough's view. He believes firmly in the capacity of social change, insofar as an individual, even under strong social domination, has the ability to rebel against it and change it. Such ability assigns new meanings to old ones.

Given this perspective, the social nature of discourse comes forward as an issue with evident historical and cultural contexts. The following section presents the methodological approach and the context in which this research was conducted.

\section{Methodology}

This work is based on an interpretive view (ERICKSON, 1986/1990), which claims that the natural context and its participants clarify what takes place in any given social situation. The aim of this approach is to show the meaning of actions in social life, as well as 
${ }^{1}$ Owned and operated by Google, Orkut was designed to help users meet new friends and maintain existing relationships. The website is named after its creator, Google employee Orkut Büyükkökten. Less popular in the United States than competitors Facebook and MySpace, it is one of the most visited websites in India and Brazil. As of October 2011, 59,1\% of Orkut users are Brazilians, followed by Indians $(27,1 \%)$ and the Japanese $(6,7 \%)$. Information extracted from http:// en.wikipedia.org/wiki/ Orkut. to give an interpretation of the interaction between the various members that make up the study group.

From this standpoint, Erickson (1986/1990) considers that the goal of interpretive research is to comprehend the universe of human language in microscopic terms. This does not mean that this approach does not take into account macrocontexts. By observing microroutines we may also understand the overall macrostructure.

The relationship between micro and macro proceeds dialectically. This research approach shares the view that each individual's sociocultural environment determines his/her social behavior.

\subsection{Research context}

To understand how the identities of English teachers are represented, this study investigated digital communities on Orkut ${ }^{1}$, one of the most popular social networking websites in Brazil. Certain criteria have been used in dealing with data. For instance, the communities first observed were those that focused directly on the Brazilian teacher of English.

This initial stage produced 141 communities, of which three were selected. Communities were chosen because of their significant number of members: "English Language Teachers" (14,189 members), "English Teachers in Brazil" (10,110 members), "I am an English Teacher" (8,564 members). The analysis took into account the images linked to these communities because, as discourse in the digital environment is multimodal, they were considered key elements in understanding members' identities. As a result, there were icons of Anglo-Saxon culture, i.e. flags or those related to a school context, such as textbooks or pictures representing the teacher's image.

Community profiles were examined and greater attention was given to topics which refer to the teaching 
profession. Two such topics are here presented as examples: "The choices of languages spoil everything" ("English Teachers in Brazil"), with ten posts, and "Public education in Brazil a wonder!!!" ("English Teachers in Brazil"), with 37 posts. These two topics have brought forth clear evidence regarding the professional identity of teachers.

\section{Data analysis}

\subsection{Identity construction elements of iconic teachers in Orkut communities}

Any image contributes ideologically to the construction of a certain reality (KRESS; VAN LEEUWEN, 2007; DORFMAN; MATTELART, 2002, FAIRCLOUGH, 2001), especially in the digital environment, in which non-verbal communication is part of its verbal counterpart. Thus, a picture in that context may reveal ideological influence and thus maintain a certain hegemonic identity which can lead the casual reader to a single meaning, translating it into an image that is portrayed so appealingly, as in the following example:

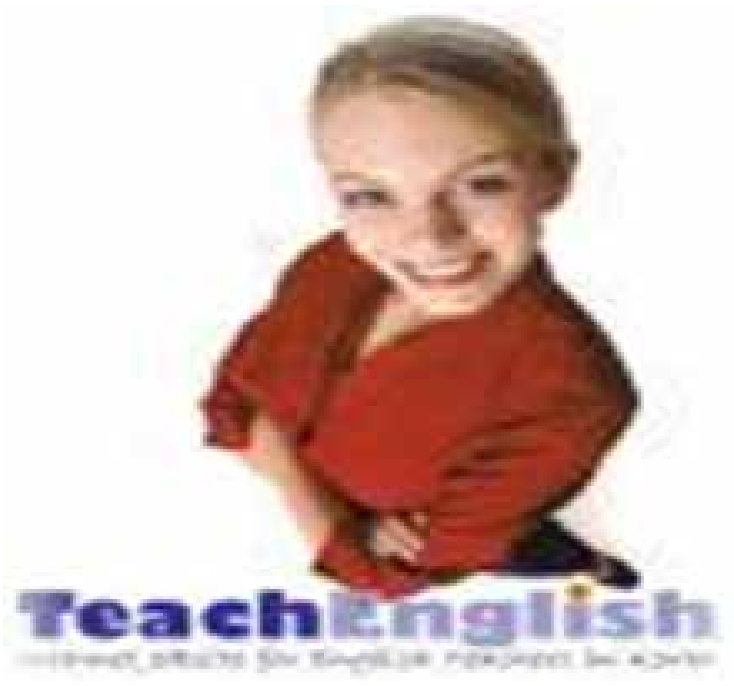

"I am an English Teacher" community 
The opening image of the community shows us a likeable teacher. The red clothes and the phrase "Teach English" in blue letters convey a symbolic message through the colours of the American flag. This figure apparently seeks to create an identification between English teachers and the "native speaker". By establishing this identification, the teacher assumes a symbolic place of "native" identity, thus relaying the values and behaviour of the dominant foreign culture. Such representation seems to corroborate the idea that learning includes something from another desire (Revuz, 1998), in this case to be an English native speaker, and therefore encourage teachers to strive for cultural and social identity. However, this desire is always incomplete and never becomes the object of idealization.

To preserve hegemonic discourse, communities introduce, sometimes inadvertently, representations of British or American culture in their images, such as these countries' national flags. This can be seen in the following example:

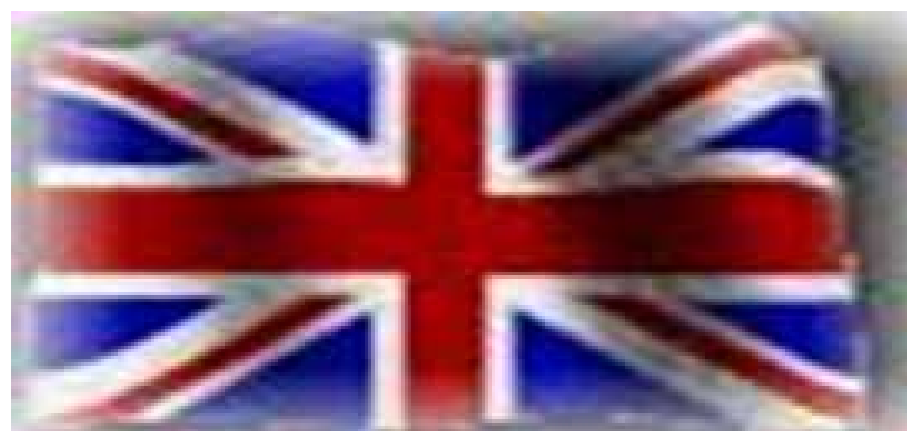

“English Language Teacher" community

The flag is a social symbol representing national identity and that leads us to the historical roots of a nation that set it apart from the rest. In this case, the "English Language Teacher" community seeks to establish 
identification between the community and British culture. This identification is apparently quite obvious, given the fact that the community is made up of English teachers. However, it also reveals a cultural hegemony which is crystallised and grounded by common sense, homogenizing teachers' discourse and selling truths that attempt to define what we should or should not be.

Thus, a teacher who sees this picture may notice just how simple is the expedient of ignoring the relationship between power and the ideological effect of such practice. This concern seems to be reflected in choices of topics (recreational activities, tips or music, textbooks, jobs, students' language errors, among others). The fact that teachers do not worry about the most critical issues regarding the teaching and learning of English may reveal a lot more about language training-centred professional identity than about social reflection-centred professional identity, based on traditional views of language teaching. This can be perceived in the following image.

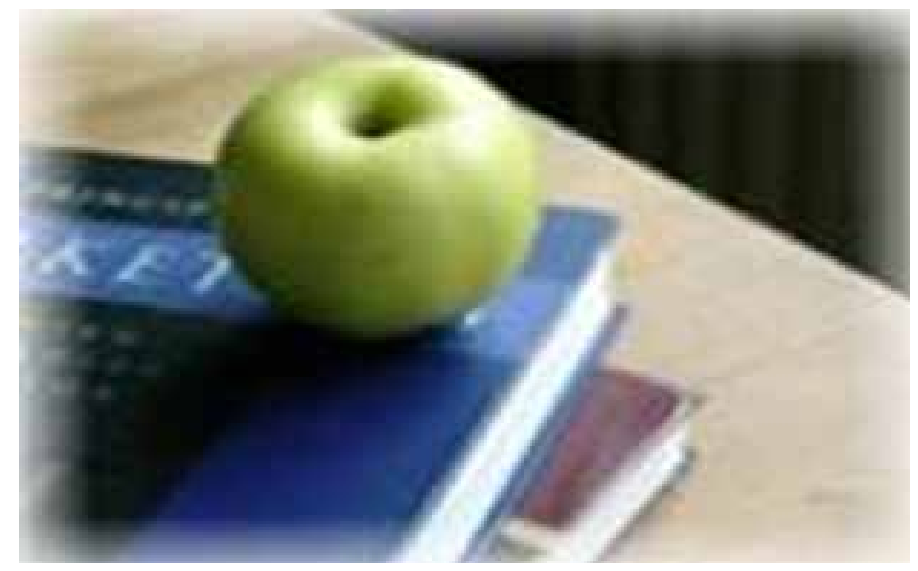

\section{"English Teachers in Brazil" community}

This image has been chosen by the "English Teachers in Brazil" community to portray representations that relate to a knowledge built mainly on textbooks. 
Traditionally, textbooks attempt to systematize and fragment linguistic aspects to make them more accessible to learners. Therefore, this learning tool organizes knowledge by presenting certain truths and regularities concerning language. This cumulative knowledge gives students the chance to progress smoothly in their learning, in order to achieve full mastery of the language. By excluding information, textbooks strengthen certain perceptions as to what it means to learn a foreign language. This symbolic construction tends to make the teacher believe that the pedagogical role of textbooks is devoid of ideologies and power relationships.

The image of the apple alludes to the notion of the tasty fruit of knowledge that must be constantly consumed by the teacher. This image of the pleasure of learning is required for the language to be widely publicized so that students, through effective methodologies, may learn. Perhaps for this reason, the observed communities seek to employ a language free from ideological conflict.

\subsection{Community profile}

Orkut communities generally highlight their goals and aspiring members' desired profiles, as in the examples below:

For all English teachers who love what they do. A space to exchange tips, experiences, difficulties and even complaints. Welcome and let's share! ( "I am an English Teacher" community).

For English language teachers from around the world who want to share thoughts and learn. Use our forum to get info, exchange ideas, make friends or simply practise your English. ("English Language Teachers" community).

This is a community for English teachers living (or not) in Brazil. It's a place for us to share 
lessons, ideas and teaching experience [...]. ( "English Teachers in Brazil" community).

The "I am an English Teacher" community seeks to assess eligible members. An initial reading of the text suggests the inclusion of any English teacher by the pronoun "all", but that expectation is dampened by the clause "who love what they do", as well as by evaluative presumptions ("A space to exchange tips, experiences, difficulties and even complaints") that attempt to classify and select the desired profile of aspiring members. Thus, the ideal participants seem to be those who have a deep feeling for the language and the teaching profession.

This image of the teacher also seems to be conveyed in other communities, mainly by verbs such as "want" and "share" which seek to emphasize experience exchanges among participants ("to share thoughts and learn", "It's a place for us to share lessons, ideas and teaching experience"), suggesting values that should be followed by those interested in becoming members. As Fairclough (2001) states, these assumptions also have an ideological and political character. By giving priority to a certain type of teacher profile, these social network communities exclude others who are not in tune with their perceptions.

\subsection{Teachers' discourse}

Many communities seem to focus on social and psychological issues, posting topics such as games, exercises, and activities to assist the teacher in his/her daily tasks. Despite the predominance of such topics, there are also debates related to the teaching profession, as can be seen in the following excerpt:

After all, who cares if her grammar (intentional cacophony) is half-assed? (And I'm being
${ }^{2}$ In Brazil, private English language schools often hire people who lived in countries like the United States or England, even if they do not have formal teaching qualifications. 
generous.) After all, she lived six years in the States, and has excellent pronunciation! And who cares if she's never done one course while she was in the U.S. because she does not have time, and therefore writes "He plaid bayzball for sum time" on the blackboard? After all, her practice has international experience, and "student is like that!" And who cares if she has zero experience in the classroom and does not take way to do that because she knows the basics of teaching, several approaches on teaching and learning, etc.? After all, what matters is that her is "child free and has a thousand stories [unitedsteakeanas] to tell", and that pleases students! [...]. ("English Language Teachers" community).

In this passage, the user begins his/her account by resorting to the indeterminacy of the subject via pronouns ("who", "she") and questions to generalize a continuing situation in language education - the fact that professional teachers often have practical experience but no academic background in the teaching and learning of foreign languages. This community member appears to challenge the common notion that gives priority to an experience abroad over university qualifications; the teacher being described "lived six years in the States" but had not undergone language training ("grammar [...] is half-assed") or teacher training. So the user is trying to disqualify teachers who, despite having "international experience", still face "difficulties" when writing simple sentences like "He plaid bayzball for sum time".

The teacher is not a teacher, but someone who approaches the imaginary "authenticity" of the English language as a result of previous experiences, of having "a thousand stories [unitedsteakeanas] to tell". Hence he/she becomes just another storyteller who simply reproduces stereotypes, without applying other abilities which may expose a complex network of contradictions within foreign language learning. This teacher tells stories 
which, according to the user in question, may also arouse more interest among foreign language learners ("and that pleases students!") and, apparently, greater success. However, what appears to be implicit in the excerpt is that a state of curiosity does not necessarily result in effective learning.

The user draws attention to the common understanding that assigns a mythical value to language experiences abroad, experiences which provide knowledge on the teaching and learning of foreign languages. The word "mythical" is appropriate in that it refers to the idea that the native speaker is the ideal model to be followed. It is this myth that gives teachers the practical conditions to become teachers, for a dip in the native culture approaches the desired representation of professional foreign language teaching that is designed to be free from impurities. For those who advocate this kind of perspective, they may forget the ideological and political implications in language acquisition as well. This does not mean that only a scholar is capable of a more critical language teaching, but the lack of reflection on the part of teachers may, in fact, bring harmful effects to the process of language learning. Teachers' working conditions and the abandonment of the profession are topics also discussed in the communities observed, as the following excerpt shows:

The profession was, has gone downhill. The other day an excellent student thinking in turn threatened my teacher, and gave him just rubs like: "It's crazy, girl? You can not live on that, no. If you really like English, like to teach and really want to teach, then choose a 'true profession' and give lessons in is our spare time as a hobby." And I concluded, looking menacingly at the bottom of his eyes: "Is that clear?" ("English Language Teachers" community). 
The user attempts to destabilize the image of the teaching profession through the definite article "the", the relational process marker "was" and the nominator "downhill", depicting a situation of hopelessness. To defend this argument, he/she recalls the example of a student interested in teaching who was completely discouraged: "gave him just rubs like: 'It's crazy, girl? You can not live on that, no". A simple token of appreciation for teaching is regarded as insanity, leaving those interested to regard it as a hobby ("give lessons in is our spare time").

On the other hand, the user condemns language teaching, hence revealing the uncertainties of his/her own professional identity. Perhaps one of the causes for the teacher's malaise lies in the social representation which portrays an unquestionable authority, the result of which is a school environment that brings forth the fragmented concept that teachers and students do not develop a critical sense about the world. Consequently, young and unmotivated teachers assume unreceptive attitudes to learning whenever they face challenges.

This fragmentation of the school curriculum is partly caused, according to Kleiman; Silva (1999), by the division of school time: series, chronological age of students, class hours which include only certain fields of knowledge. By being assigned a "perfect time" for certain activities, students are conditioned to accept external learning as a syllabus requirement. The school obsessively seeks to homogenize them and, in so doing, does not take into account their individual differences. Thus, over time, this dominant paradigm becomes a straitjacket for pedagogical work. In elementary school, the teacher decides what to do and the time to do it, whereas, by following series, time is rigidly shared between different subjects and teachers. 
However, the teacher is almost always unable to fully control the actions that take place within the classroom. Students employ certain strategies - lack of discipline, parallel conversation, drowsiness, play - in order to deal with teacher-dominant speech. Therefore, students often declare war against the teacher, in many cases seriously undermining his/her authority. The teacher, as a consequence of these events, feels displaced and despondent, and by losing hope is expelled from his/ her position by the new generation, eager to share power. We may infer this in light of the following excerpt:

I am also an English teacher. I taught eight years ago and realized something.We English teachers are in the process of "extinction", if you do not believe, wait and see. The deal is that to learn English today is much easier and the students can use the resources that are increasingly available to meet their needs through songs and movies and the like. In fact, we have to seek employment through public contests. While you are a private school professorzinho you may not realize, but it's replacement will only last until the "flavor of the month", it is natural and logical. And the car, thank you being able to have one, have many teachers in your same situation that neither car has. ("English Language Teachers" community).

The user describes him/herself as an experienced teacher: "I am also an English teacher. I taught eight years ago." He/she refers to a rapid disappearance of the teaching profession: "We English teachers are in the process of 'extinction', if you do not believe, wait and see." The profession seems to be regarded as fruitless by contemporary society: "students can [...] meet their needs through songs and movies and the like." However, what the user fails to realize is that the professional on the verge of extinction is of another type: one that is in line with the traditional school structure that sometimes 
turns him/her into a victim/villain of the system. This professional is also alienated by bureaucratic activities (filling papers and reports) in an excessive number of classes that do not leave room for sharing ideas, planning lessons, or studying.

This process is contradictory, given the fact that society demands a professional attuned to new ways of teaching, but at the same time offers few opportunities for him/her to embrace new experiences. Public educational environment is, in turn, seen as an alternative place for professional language teachers.

Spurred on by economic issues, teaching ends up being regarded as meaningless work that is devoid of reflection or criticism. The teacher's job is similar to that of Sisyphus (OLIVEIRA, 2003), who is condemned by Zeus to roll a stone eternally up a hill. Upon reaching the top, the stone rolls down again, forcing him to start over, as he was not allowed to let the rock roll towards the abyss. A teacher's work often appears to reproduce the tragic fate of the Greek character - something that does not cease to repeat itself evenly and regularly, as if it were imposed by the gods. The teacher feels discredited in realizing that, given economic and social conditions, the content he/she teaches only affects the improvement of the lives of their students.

In summary, according to Ponce (1997), the employment contract of Brazilian teachers, based on chronological time computed with student-to-school time, creates a situation which takes on meaning in the following excerpt:

It is an absurd hour/class of profs. English. I graduated in translator/interpreter (English / Portuguese) and Full Degree, I can teach and justly by the "salary", if I may call, I gave up definitily teaching. ("English Language Teachers" community). 
The user expresses his/her indignation about the hours of language classes: "It is an absurd hour/class of profs. English." This system seems to deny the teacher's full labor rights, i.e. to receive payment for the hours spent away from the classroom. In the best work settings found in Brazil, the teacher is paid for weekly meetings, which often end up being used only to solve specific problems of a bureaucratic nature. Therefore, teachers' working time encompasses predicting their actions with students in the classroom, which reinforces the concept of teacher as a mere performer of tasks. Even though this does not mean that there is a determining factor between teacher salary and student performance, we cannot deny that this variable contributes to the growing exodus of teachers to other more economically profitable professions: "I gave up definitily teaching."

The situation described in the above passage may be an example of why some disillusioned educators do not come forward. Isolation in educational settings makes it difficult to recognize the positive effects of efforts implemented by fellow teachers, raising, in some cases, negative reactions towards those efforts.

\section{Final remarks}

The idea for this study originated from curiosity about the identity of the professional English language teacher in Orkut communities. Studying a social network found encouragement in the growing number of people who use the internet as a place of social interaction, as well as in the influence of digital environment in everyday life. Through the analysis of three Orkut communities, this study focused on the lexical choices and nonverbal messages used by their members, showing how participants characterized and linked these communities to "reality" in their texts. 
The research revealed that discourse is rooted in the notion of a more traditional professional identity, forged in a school tradition. According to Fairclough (2001), language options are not born by chance, but instead are directly related to social and cultural processes in a broader sense of contemporary society which, in many cases, we are not aware of. That is not to say that such options are merely the result of those constraints. Fairclough (2001) believes that it is possible to unveil and perhaps change certain concepts that nourish hegemonic discourse, that is, we may reflect upon and (re)form school so that one day we may construct a more egalitarian learning environment.

The analysis of Orkut communities brings to the fore an "identity crisis" for some language educators and reveals the constant contradiction, fluidity, resistance, marginality or compliance criss-crossing the teaching profession. We live in times of risks and uncertainties. Dealing with this issue is a decisive factor for the professional educator not to surrender his/her attempt at self-improvement. This difficulty, in the words of Celani (2004), is explained partly by the lack of a secure knowledge base from whence to experience the effects of learning and its potential for transformation. This fact generates distress and gives rise to contradictory and challenging works by teachers in such times of great change. To overcome this, it is up to teachers to develop a critical judgement that assists their autonomy (CELANI, 2004) and prepares them to face the various challenges of unpredictable situations. Risk must be accepted as a natural process of life, for every educational process relates to uncertainty of one form or another. We need to face up to the natural challenges that move human progress.

Teachers' discourse simply demonstrates the need for a critical linguistic approach that promotes discussion on the effects of ideologies that mask and 
conceal the subject. Teachers' professional identity must cross symbolic boundaries (HALL, 2000) that may cause disruption, and the effect may be seen in hopelessness, in withdrawal or in the confrontation of hegemonic ideological forces that mobilize actions seeking changes in our education. 


\section{References}

ASSIS-PETERSON, A.A; SILVA, E.M.N. Não tenho estoque de sonhos para me manter em pé: construção de identidades de uma professora de inglês. In BARROS, S.M; ASSISPETERSON, A. A formação crítica de professores de línguas: desejos e possibilidades. São Carlos: Pedro \& João Editores, 2010, p.145-174.

ASSIS-PETERSON, A.A; COX, M.I.P. Ser/estar professor de inglês no cenário da escola pública: em busca de um contexto eficaz de ensino/aprendizagem. Polifonia, n. 05, Cuiabá: Edufmt, 2002, p. 1-26.

CELANI, M.A.A.; MAGALHÃES, M.C. Representações de professores de inglês como língua estrangeira sobre suas identidades profissionais: uma proposta de reconstrução. In: MOITA LOPES, L.P.; BASTOS, L.C.B (Org.). Identidades recortes multi e interdisciplinares. Campinas, São Paulo: Mercado de Letras, 2002, p.319-338.

CELANI, M.A. C. Culturas de Aprendizagem: Risco, Incerteza e Educação. In MAGALHÃES, M.C.C (org.). $A$ formação do professor como um profissional Crítico: linguagem e reflexão. São Paulo: Mercado de Letras, 2004, p.135-160.

CORACINI, M.J.R.F. Subjetividade e identidade do (a) professor (a) de português. In CORACINI, M.J.R.F (Org.). Identidade e discurso. Campinas, São Paulo: Argos, 2003, p. 239-255.

CUNHA, A G. Dicionário Etimológico Nova Fronteira de Língua Portuguesa. Rio de Janeiro: Nova Fronteira, 1991.

DORFMAN, A.; MATTELART, A. Para ler o pato Donald: comunicação de massa e colonialismo. Tradução Álvaro de Moya, 2a Ed. Rio de Janeiro: Paz e Terra, 1980.

ERICKSON, ERICKSON, F. Qualitative methods in research on teaching. handbook of the research on teaching. 3d edition. M. WITTROCK, 1986/1990 ed. New York: 
Macmillan. Also, quantitative methods; Qualitative Methods (with R. Linn) AEREA, Research in Teaching and Learning, volume 2. New York : Macmillan.

FABRÍCIO, B.F.; MOITA LOPES, L.P. A dinâmica dos (re) posicionamentos de sexualidade em práticas de letramento escolar. In: MOITA LOPES, L.P.; BASTOS, L.C.B (Org.). Para além da identidade: fluxos, movimentos e trânsitos. Belo Horizonte: Editora da UFMG, 2010, p.283-314.

FAIRCLOUGH, N. Discurso e mudança social. Tradução Izabel Guimarães, Brasília: Editora da UNB, 2001.

FOUCAULT, M. A arqueologia do Saber. São Paulo: Vozes, 1971.

FULLAN, M.; HARGREAVES, A. A escola como organização aprendente: buscando uma educação de qualidade. São Paulo: Artmed, 2000.

GRIGOLETTO, M. Leituras sobre a identidade: contingência, negatividade e invenção. In: MAGALHÃES, I, CORACINI, M.J.; GRIGOLETTO, M. (Org.). Práticas identitárias: língua e discurso. São Carlos: Clara Luz, 2006: p.15-44.

HALL, S. Quem precisa de identidade? In: SILVA, T.T.; HALL; WOODWARD, K. (Orgs.). Identidade e diferença: a perspectiva dos estudos culturais. Tradução: Tomáz Tadeu da Silva. Petrópolis, RJ: Vozes, 2000: p. 103-133.

JESUS, D.M. “Eu amo a língua portuguesa!": o discurso de usuários do Orkut. Revista Polifonia, n. 17, GELCO, Cuiabá: Editora da UFMT, 2009: p. 239-253.

KLEIMAN, A B.; SILVIA, E. MORAES. Leitura e interdisciplinaridade: Tecendo Redes nos Projetos da Escola. Campinas, SP: Mercado de Letras, 1999.

KRESS, G.; VAN LEEUWEN, T.V. Reading images: the grammar of visual design. 2. ed. London/New York:

Routledge, 2007. 
MACHADO, R.O.A. A Fala do Professor de Inglês como Língua Estrangeira: Alguns Subsídios para a Formação do Professor. Dissertação de Mestrado, IEL, UNICAMP, Campinas, 1995.

MAGALHÃES, I. Discurso, ética e identidade de gênero. In MAGALHÃES, I.; CORACINI, M.J.; GRIGOLETTO, M. (Org.). Práticas Identitárias: língua e discurso. São Carlos: Clara Luz, 2006: p.71-96.

MOITA LOPES, L.P (Org.). Discursos de identidades: discurso como espaço de construção de gênero, sexualidade, raça $e$ profissão na escola e na família. Campinas, SP: Mercado de Letras, 2003.

NASIO, J.D. Os 7 conceitos cruciais da psicanálise. Rio de Janeiro: Zahar, 1995.

OLIVEIRA, E.S.G. Trabalho de professor - trabalho de Sísifo? a heróica dimensão da docência. In: VIELLA, M. A (org.) Tempos e Espaços de Formação. Chapecó: Argos, 2003: p. 197218.

PASSOS, L.A. Currículo, Tempo e Cultura. Tese de Doutorado, Educação e Currículo, PUC-SP, São Paulo, 2003.

PONCE, B. J. O Tempo na Construção da Docência. Tese de Doutorado, Educação e Currículo, São Paulo, 1997.

REVUZ, C. A. língua estrangeira entre o desejo de um outro lugar e o risco do exílio, Tradução: S.Serrani-Infante. In: I. SIGNORINI, I. (Org.), Lingua(gem) e identidade. Campinas: Mercado de Letras, 1998: p. 213-230.

SANTIAGO, M. E. V. EFL teachers' discourse at Orkut: agency from the perspective of systemic functional linguistics and structuration theory. Revista Intercâmbio, volume XVII, São Paulo: LAEL/PUC-SP, 2008, p. 322-343. 
SANTOS, M. L.P. Mulheres e a constituição da leitura em um evento de letramento: intertextualidade e identidade social. In: MOITA LOPES, L.P. (Org.). Discursos de identidades. Campinas, SP: Mercado de Letras, 2003, p. 157-180.

UCHÔA-FERNANDES, J.A. Jogos de se mostrar/dizer: o sujeito e os discursos de língua inglesa na rede social Orkut. Dissertação de Mestrado, USP, FFCH, São Paulo, 2008.

VEREZA, S.C. Quem fala por mim?: identidade na produção discursiva em língua estrangeira. In: MOITA LOPES, L.P.; BASTOS, L.C.B. (Org.). Identidades, recortes multi e interdisciplinares. Campinas, SP: Mercado de Letras, 2002, p. 351-361.

WOODWARD, K. Identidade e diferença: uma introdução teórica e conceitual. In SILVA, T.T, HALL, S; WOODWARD, K. (Orgs.). Identidade e Diferença: a perspectiva dos estudos culturais. Tradução: Tomáz Tadeu da Silva. Petrópolis, RJ:

Vozes, 2000.

Recebido em 27/02/2014

Aceito para publicação em 30/07/2014 